\title{
Modeling suspended sediment sources and transport in the Ishikari River basin, Japan, using SPARROW
}

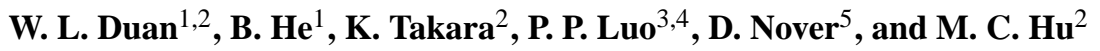 \\ ${ }^{1}$ Key Laboratory of Watershed Geographic Sciences, Nanjing Institute of Geography and Limnology, \\ Chinese Academy of Sciences, Nanjing, 210008, China \\ ${ }^{2}$ Disaster Prevention Research Institute, Kyoto University, Kyoto, Japan \\ ${ }^{3}$ Institute of Hydraulic Structure Engineering and Water Environment, College of Civil Engineering and Architecture, \\ Zhejiang University, Hangzhou, Zhejiang, China \\ ${ }^{4}$ Institute for the Advanced Study of Sustainability, United Nations University, Shibuya, Tokyo, Japan \\ ${ }^{5}$ AAAS Science and Technology Policy Fellow, US Environmental Protection Agency, Global Change Research Group, \\ Washington, D.C., 20010, USA
}

Correspondence to: W. L. Duan (duan.scut.cn@gmail.com), B. He (hebin@niglas.ac.cn), and P. P. Luo (luoping198121@gmail.com)

Received: 13 September 2014 - Published in Hydrol. Earth Syst. Sci. Discuss.: 6 October 2014

Revised: - - Accepted: 15 February 2015 - Published: 6 March 2015

\begin{abstract}
It is important to understand the mechanisms that control the fate and transport of suspended sediment (SS) in rivers, because high suspended sediment loads have significant impacts on riverine hydroecology. In this study, the SPARROW (SPAtially Referenced Regression on Watershed Attributes) watershed model was applied to estimate the sources and transport of SS in surface waters of the Ishikari River basin $\left(14330 \mathrm{~km}^{2}\right)$, the largest watershed in Hokkaido, Japan. The final developed SPARROW model has four source variables (developing lands, forest lands, agricultural lands, and stream channels), three landscape delivery variables (slope, soil permeability, and precipitation), two in-stream loss coefficients, including small streams (streams with drainage area $<200 \mathrm{~km}^{2}$ ) and large streams, and reservoir attenuation. The model was calibrated using measurements of SS from 31 monitoring sites of mixed spatial data on topography, soils and stream hydrography. Calibration results explain approximately $96 \%\left(R^{2}\right)$ of the spatial variability in the natural logarithm mean annual SS flux $\left(\mathrm{kg} \mathrm{yr}^{-1}\right)$ and display relatively small prediction errors at the 31 monitoring stations. Results show that developing land is associated with the largest sediment yield at around $1006 \mathrm{~kg} \mathrm{~km}^{-2} \mathrm{yr}^{-1}$, followed by agricultural land $\left(234 \mathrm{~kg} \mathrm{~km}^{-2} \mathrm{yr}^{-1}\right)$. Estimation of incremental yields shows
\end{abstract}

that $35 \%$ comes from agricultural lands, $23 \%$ from forested lands, $23 \%$ from developing lands, and $19 \%$ from stream channels. The results of this study improve our understanding of sediment production and transportation in the Ishikari River basin in general, which will benefit both the scientific and management communities in safeguarding water resources.

\section{Introduction}

Suspended sediment (SS) is ubiquitous in aquatic ecosystems and contributes to bottom material composition, watercolumn turbidity, and chemical constituent transport. However, sediment is the largest water pollutant by volume, and excessive sediment can have dramatic impacts on both water quality and aquatic biota (Bilotta and Brazier, 2008). High turbidity can significantly reduce or limit light penetration into water, with implications for primary production and for populations of fish and aquatic plants. In addition, excessive sedimentation can bring more pollutants containing organic matter, animal or industrial wastes, nutrients, and toxic chemicals, because sediment comes mainly from forest lands, agricultural fields, highway runoff, construction 
sites, and mining operations (Le et al., 2010; Srinivasa et al., 2010), which always cause water quality deterioration and therefore are a common and growing problem in rivers, lakes and coastal estuaries (Dedkov and Mozzherin, 1992; Ishida et al., 2010; Meade et al., 1985). Eutrophication due to nutrient pollution, for example, is a widespread sediment-related problem recognized at sites world-wide (Conley et al., 2009). Also, in the US, approximately $25 \%$ of the stream length (167 092 miles) has been negatively impacted by excessive sediment loads (USEPA, 2006).

Similarly, sediment accumulation can reduce the transport capacity of roadside ditches, streams, rivers, and navigation channels and the storage capabilities of reservoirs and lakes, which cause more frequent flooding. For example, dams will gradually lose their water storage capacity as sediment accumulates behind the dam (Fang et al., 2011); erosion of river banks and increased sedimentation are also impacting the Johnstone River catchment (Hunter and Walton, 2008) and the estuary in the Tuross River catchment of coastal southeastern Australia (Drewry et al., 2009) in clogging of land and road drainage systems and river systems. Therefore, as SS is fundamental to aquatic environments and impairments due to enhanced sediment loads are increasingly damaging water quality and water resource infrastructure, it is extremely important to develop both monitoring systems and technologies to track and to reduce the volume of SS in order to safeguard freshwater systems.

Sediment sources can be separated into sediment originating in upland regions, sediment from urban areas, and sediment eroded from channel corridors (Langland and Cronin, 2003). Land use impacts are commonly seen as resulting in increased sediment loads and therefore as an inadvertent consequence of human activity. Moreover, land use and land use change are also important factors influencing erosion and sediment yields. For example, urbanization may ultimately result in decreased local surface erosion rates when large areas are covered with impervious surfaces such as roadways, rooftops, and parking lots (Wolman, 1967); because of the increased exposure of the soil surface to erosive forces as a result of the removal of the native vegetative cover, agricultural lands can drastically accelerate erosion rates (Lal, 2001). In addition, stream channel erosion can be a major source of sediment yield from urbanizing areas (Trimble, 1997).

In the Japanese context, high suspended sediment loads are increasingly recognized as an important problem for watershed management (Mizugaki et al., 2008; Somura et al., 2012). For example, the Ishikari River basin has long been plagued by high suspended sediment loads, generally causing high turbidity along the river, including in Sapporo, Hokkaido's economic and government center. The pervasiveness of the problem has generated several sediment management studies in the Ishikari River basin. Asahi et al. (2003) found that it is necessary to consider tributary effects directly and that sediment discharged from tributaries contributes to the output sediment discharged from the river's mouth.
Wongsa and Shimizu (2004) indicated that land use change has a significant effect on soil eroded from hill slopes, but no significant effect on flooding for the Ishikari River basin. Ahn et al. (2009) concluded that sedimentation rate increased in the Ishikari River floodplain because of agricultural development on the floodplains. However, detailed accounting of sediment sources (e.g., the type of land use) and transport in the Ishikari River basin remains poorly understood.

Computer-based modeling is an essential exercise both for organizing and understanding the complex data associated with water quality conditions and for development of management strategies and decision support tools for water resource managers (Somura et al., 2012). Recent applications of the GIS-based SPAtially Referenced Regression On Watershed attributes (SPARROW) (Smith et al., 1997) watershed model in the United States have advanced understanding of nutrient sources and transport in large regions such as the Mississippi River basin (Alexander et al., 2000, 2007) and smaller watersheds such as the Chesapeake Bay watershed (Brakebill et al., 2010) and those draining to the North Carolina coast (McMahon et al., 2003).

In this study, we use the SPARROW principle and framework to develop a regional-scale sediment transport model for the Ishikari River basin in Hokkaido, Japan. The concrete objectives are (1) to calibrate SS SPARROW for the Ishikari River basin on the basis of 31 stations, (2) to use the calibrated model to estimate mean annual SS conditions, and (3) to quantify the relative contribution of different SS sources to in-stream SS loads. These efforts are undertaken with the ultimate goal of providing the information on total and incremental sediment loads in different sub-basins that will help resource managers identify priority sources of pollution and mitigate this pollution in order to safeguard water resources and protect aquatic ecosystems.

\section{Materials and methods}

\subsection{Study area}

The Ishikari River, the third longest river in Japan (Fig. 1), originates from Mt. Ishikaridake (elevation $1967 \mathrm{~m}$ ) in the Taisetsu Mountains of central Hokkaido, passes through the west of Hokkaido, and flows into the Sea of Japan, with a total sediment discharge of around $14.8 \mathrm{~km}^{3}$ per year. The river has the largest river basin, with a total drainage area of $14330 \mathrm{~km}^{2}$, the north-south and east-west distances of which are about 170 and $200 \mathrm{~km}$, respectively. The Ishikari plain occupies most of the basin's area, which is surrounded by rolling hills and is the lowest land in Japan (the highest elevation is less than $50 \mathrm{~m}$ ) and consequently the best farming region in the country. The Ishikari River basin has cold snowy winters and warm, non-humid summers. Sediment load is very low in the cold winter except for the temporary snowmelt at positive degree air temperature, and high in the 


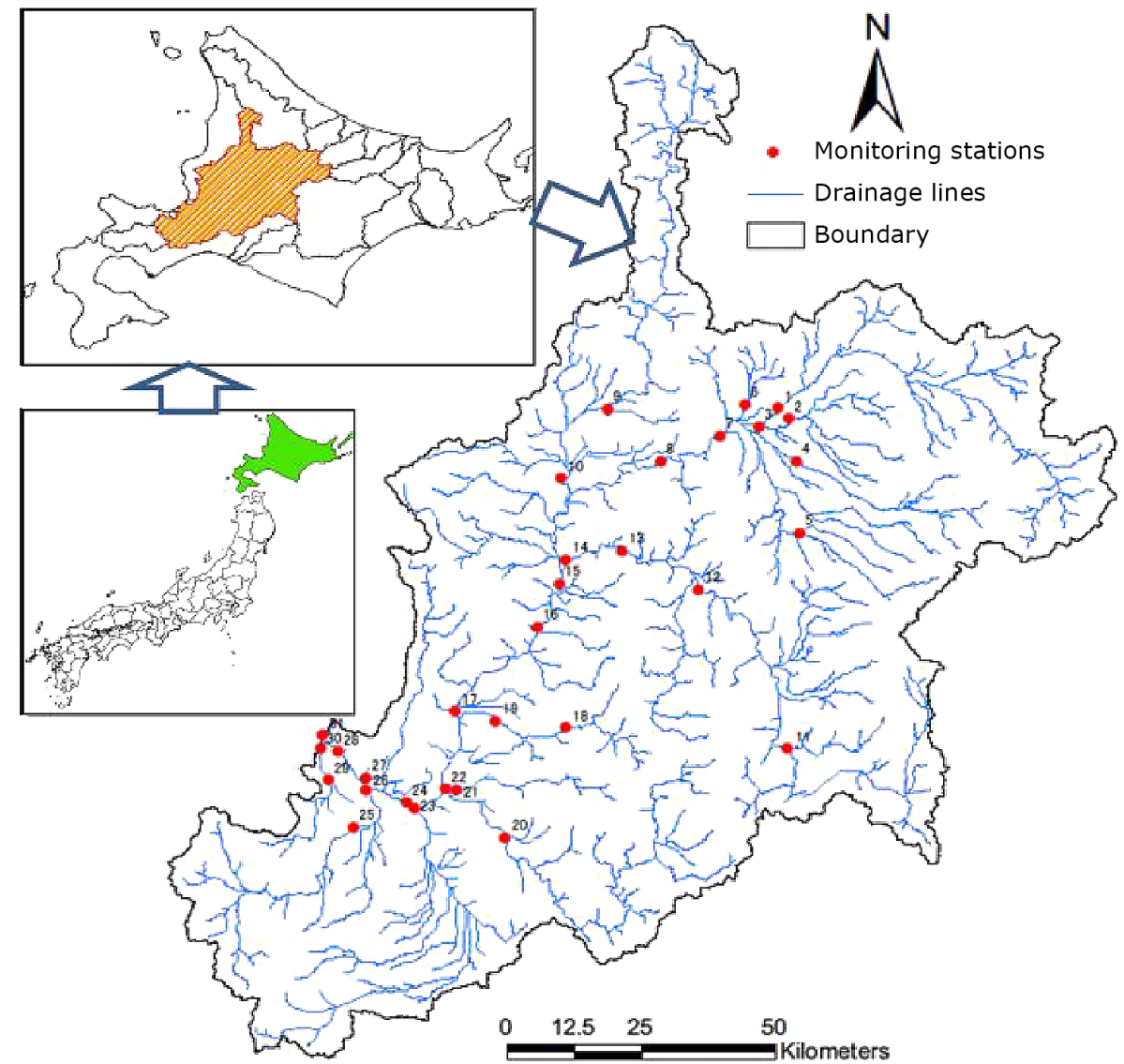

Figure 1. Study area, stream networks, and monitoring stations for the Ishikari River basin.

snowmelt season of mid-March to May and heavy rainfalls in May-late November. In this basin, the regional average $\mathrm{Au}-$ gust temperature ranges from 17 to $22^{\circ} \mathrm{C}$, while the average January temperature ranges from -12 to $-4{ }^{\circ} \mathrm{C}$; the regional annual precipitation was $850-1300 \mathrm{~mm}$ from 1980 to 2011.

\subsection{Modeling tools}

Based on the mechanistic mass transport components, including surface-water flow paths (channel time of travel, reservoirs), non-conservative transport processes (i.e., firstorder in-stream and reservoir decay), and mass-balance constraints on model inputs (sources), losses (terrestrial and aquatic losses/storage), and outputs (riverine nutrient export), the SPARROW modeling approach performs a nonlinear least-squares multiple regression to describe the relation between spatially referenced watershed and channel characteristics (predictors) and in-stream load (response) (Schwarz et al., 2006). This allows nutrient supply and attenuation to be tracked during water transport through streams and reservoirs and assesses the natural processes that attenuate constituents as they are transported from land and upstream (Preston et al., 2009). Figure 2 gives a graphical description of the SPARROW model components. Monitoring station flux esti- mation refers to the estimates of long-term flux used as the response variable in the model. Flux estimates at monitoring stations are derived from station-specific models that relate contaminant concentrations from individual water quality samples to continuous records of streamflow time series. To obtain reliable unbiased estimates, the Maintenance of Variance-Extension type 3 (MOVE.3) and the Load Estimator (LOADEST) regression model were applied to develop regression equations and to estimate monitoring station flux (for calculation details, see Duan et al., 2013a, b).

For the model-estimated flux, the SPARROW modeling can generally be defined by the following equation (Alexander et al., 2007):

$$
\begin{aligned}
F_{i}^{*} & =\left[\left(\sum_{j \in J(i)} F_{j}^{\prime}\right) A\left(\boldsymbol{Z}_{i}^{\mathrm{S}}, \boldsymbol{Z}_{i}^{\mathrm{R}} ; \boldsymbol{\theta}_{\mathrm{S}}, \boldsymbol{\theta}_{\mathrm{R}}\right)\right. \\
& \left.+\left(\sum_{n=1}^{N_{\mathrm{S}}} S_{n, i} \alpha_{n} D_{n}\left(\boldsymbol{Z}_{i}^{D} ; \boldsymbol{\theta}_{D}\right)\right) A^{\prime}\left(\boldsymbol{Z}_{i}^{\mathrm{S}}, \boldsymbol{Z}_{i}^{\mathrm{R}} ; \boldsymbol{\theta}_{\mathrm{S}}, \boldsymbol{\theta}_{\mathrm{R}}\right)\right] \varepsilon_{i},
\end{aligned}
$$

where $F_{i}^{*}$ is the model-estimated flux for contaminants leaving reach $i$. The first summation term represents the sediment flux that leaves upstream reaches and is delivered downstream to reach $i$, where $F_{j}^{\prime}$ denotes measured sediment 


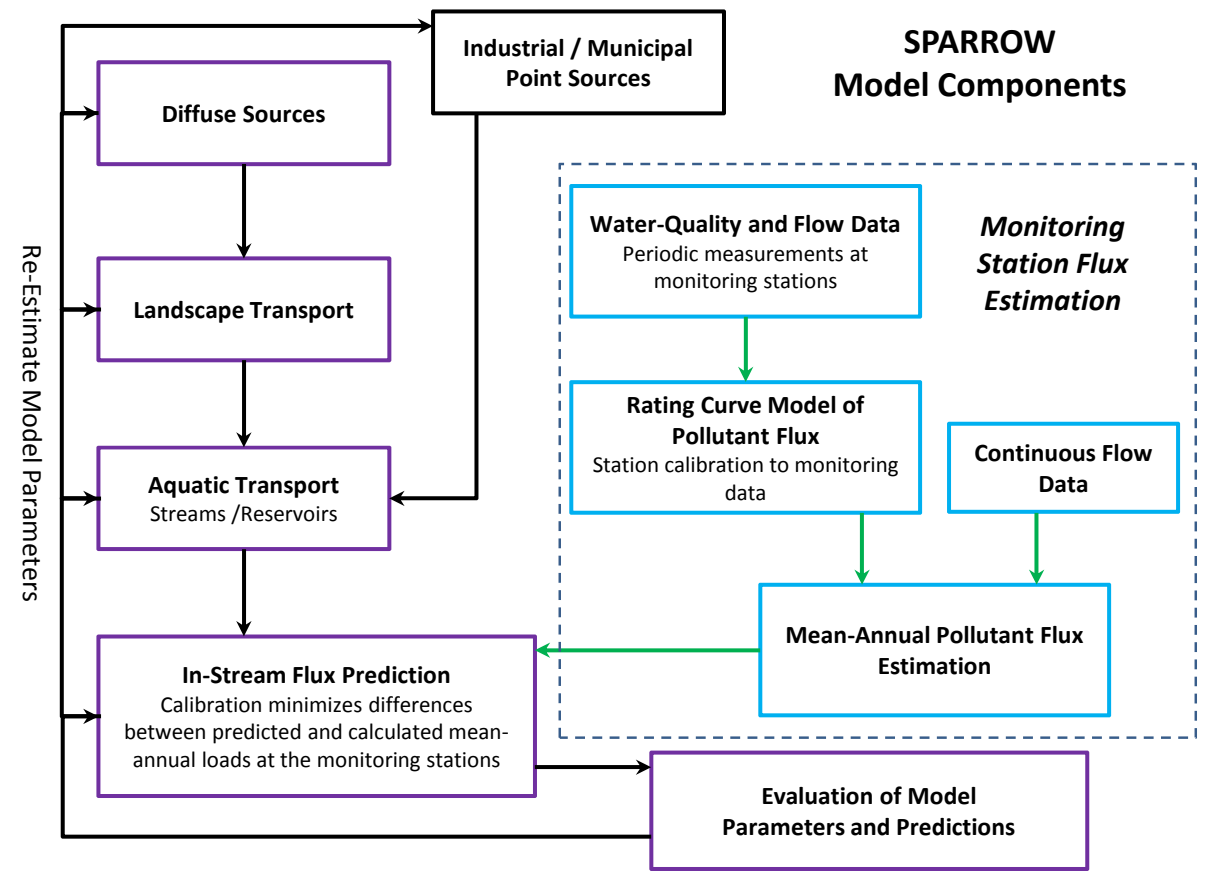

Figure 2. Schematic of the major SPARROW model components (from Schwarz et al., 2006).

flux $\left(F_{j}^{\mathrm{M}}\right)$ when upstream reach $j$ is monitored and equals the given model-estimated flux $\left(F_{j}^{*}\right)$ when it is not. $A(\cdot)$ is the stream delivery function representing sediment loss processes acting on flux as it travels along the reach pathway, which defines the fraction of sediment flux entering reach $i$ at the upstream node that is delivered to the reach's downstream node. $Z^{\mathrm{S}}$ and $Z^{\mathrm{R}}$ represent the function of measured stream and reservoir characteristics, respectively, and $\boldsymbol{\theta}_{\mathrm{S}}$ and $\boldsymbol{\theta}_{\mathrm{R}}$ are their corresponding coefficient vectors. Here, stream reach and watershed characteristics such as stream length, direction of water flow, connectivity, mean annual streamflow, water travel time per unit length, reservoir characteristics like surface area, and local and total drainage area, were present in the digital stream network data set and reflect parameters required by the model. The second summation term denotes the amount of sediment flux introduced to the stream network at reach $i$, which is composed of the flux originating from specific sediment sources, indexed by $n=1,2, \ldots, N_{\mathrm{S}}$. Each source has a source variable, denoted $S_{n}$, and its corresponding source-specific coefficient $\alpha_{n}$. This coefficient retains the units that convert the source variable units to flux units. The function $D_{n}(\bullet)$ represents the land-to-water delivery factor. The land-to-water delivery factor is a source-specific function of a vector of delivery variables, denoted by $\boldsymbol{Z}_{i}^{\theta}$, and an associated vector of coefficients $\boldsymbol{\theta}_{D}$. The function $A^{\prime}(\bullet)$ represents the fraction of flux originating in and delivered to reach $i$ that is transported to the reach's downstream node and is similar in form to the stream delivery factor defined in the first summation term of the equation. If reach $i$ is classified as a stream (as opposed to a reservoir reach), the sediment introduced to the reach from its incremental drainage area receives the square root of the reach's full in-stream delivery. This assumption is consistent with the notion that contaminants are introduced to the reach network at the midpoint of reach $i$ and thus are subjected to only half of the reach's time of travel. Alternatively, for reaches classified as reservoirs, we assume that the sediment mass receives the full attenuation defined for the reach. The multiplicative error term in Eq. (1), $\varepsilon_{i}$, is applicable in cases where reach $i$ is a monitored reach; the error is assumed to be independent and identically distributed across independent sub-basins in the intervening drainage between stream monitoring stations. This item can also be used for unmonitored reaches.

The reach loss and reservoir loss are used as the mediating factors affecting the mobilization of sediment from the stream network. The reach-loss variable is nonzero only for stream reaches, and is defined for two separate classes, shallow-flowing (small) streams versus deep-flowing (large) streams. Since stream depth is not known, streams with drainage area $<200 \mathrm{~km}^{2}$ are classified as shallow, small streams. The reservoir loss is denoted by areal hydraulic load of the reservoir, which is computed as the quotient of mean annual impoundment outflow and surface area (Hoos and McMahon, 2009). Sediment loss in streams is modeled according to a first-order decay process (Chapra, 1997; Brakebill et al., 2010) in which the fraction of the sediment mass originating from the upstream node and transported along reach $i$ to its downstream node is estimated as a continuous function of the mean water time of travel $\left(T_{i}^{\mathrm{S}}\right.$; units of time) and mean water depth, $D_{i}$, in reach $i$, such that 
Table 1. Summary of input data and calibration parameters. References to data sources are in the main text.

\begin{tabular}{|c|c|c|}
\hline Category & Input data & Data source \\
\hline $\begin{array}{l}\text { The stream } \\
\text { network }\end{array}$ & $\begin{array}{l}\text { Stream network, stream lengths, } \\
\text { sub-catchment boundaries, } \\
\text { sub-catchment areas }\end{array}$ & $\begin{array}{l}\text { Automated catchment delineation based on } \\
\text { a } 50 \mathrm{~m} \text { DEM, with modification of flow } \\
\text { diversions }\end{array}$ \\
\hline $\begin{array}{l}\text { Stream } \\
\text { load data }\end{array}$ & Water quality monitoring station & $\begin{array}{l}\text { Thirty-one stations from the National } \\
\text { Land with Water Information } \\
\text { monitoring network from } 1982 \text { to } 2010\end{array}$ \\
\hline $\begin{array}{l}\text { Sediment } \\
\text { source data }\end{array}$ & $\begin{array}{l}\text { Developing land, forest land, } \\
\text { and agricultural land }\end{array}$ & $\begin{array}{l}\text { Land use data including developing } \\
\text { land, forest land, agricultural land from } \\
\text { the Ministry of Land, Infrastructure, } \\
\text { Transport and Tourism, Japan, } 2006\end{array}$ \\
\hline \multirow{4}{*}{$\begin{array}{l}\text { Environmental } \\
\text { setting } \\
\text { data }\end{array}$} & Mean annual precipitation & $\begin{array}{l}\text { The 20-year (1990-2010) average from the } \\
\text { Japanese Meteorological Agency }\end{array}$ \\
\hline & Catchment slope & $\begin{array}{l}\text { Mean value of local slope, obtained from } \\
50 \mathrm{~m} \text { DEM }\end{array}$ \\
\hline & Soil texture, soil permeability & $\begin{array}{l}\text { Obtained from the } 1: 5000000 \text {-scale } \\
\text { FAO/UNESCO Soil Map of the World } \\
\text { and the National and Regional Planning } \\
\text { Bureau, Japan }\end{array}$ \\
\hline & Reservoir (dam) loss & $\begin{array}{l}\text { The Japan Dam Foundation } \\
\text { (http://damnet.or.jp/) }\end{array}$ \\
\hline
\end{tabular}

$A\left(Z_{i}^{\mathrm{S}}, Z_{i}^{\mathrm{R}} ; \theta_{\mathrm{S}}, \theta_{\mathrm{R}}\right)=\exp \left(-\theta_{\mathrm{S}} \frac{T_{i}^{\mathrm{S}}}{D_{i}}\right)$,

where $\theta_{\mathrm{S}}$ is an estimated mass-transfer flux-rate coefficient in units of $\mathrm{L} \mathrm{T}^{-1}$. The rate coefficient is independent of the properties of the water volume that are proportional to water volume, such as streamflow and depth (Eq. 3). The rate can be re-expressed as a reaction rate coefficient $\left(\mathrm{T}^{-1}\right)$ that is dependent on water-column depth by dividing by the mean water depth.

Sediment loss in lakes and reservoirs is modeled according to a first-order process (Chapra, 1997; Brakebill et al., 2010) in which the fraction of the sediment mass originating from the upstream reach node and transported through the reservoir segment of reach $i$ to its downstream node is estimated as a function of the reciprocal of the areal hydraulic load $\left(q_{i}^{\mathrm{R}}\right)^{-1}$ (units of $\mathrm{TL}^{-1}$ ) for the reservoir associated with reach $i$ and an apparent settling velocity coefficient $\left(\theta_{\mathrm{R}}\right.$; units of length $\mathrm{T}^{-1}$ ), such that

$A\left(Z_{i}^{\mathrm{S}}, Z_{i}^{\mathrm{R}} ; \theta_{\mathrm{S}}, \theta_{\mathrm{R}}\right)=\frac{1}{1+\theta_{\mathrm{R}}\left(q_{i}^{\mathrm{R}}\right)^{-1}}$.

The areal hydraulic load is estimated as the quotient of the outflow discharge to the surface area of the impoundment.

\subsection{Input data}

In this study, input data for building SPARROW models are classified into (Table 1) (1) stream network data to define stream reaches and catchments of the study area; (2) loading data for many monitoring stations within the model boundaries (dependent variables); (3) sediment source data describing all of the sources of the sediment being modeled (independent variables); and (4) data describing the environmental setting of the area being modeled that causes statistically significant variability in the land-to-water delivery of sediment (independent variables). Input data types are described in more detail below.

\subsubsection{The stream network}

The hydrologic network used for the SPARROW model of the Ishikari River basin is derived from a $50 \mathrm{~m}$ digital elevation model (DEM) (Fig. 1), which has 900 stream reaches, each with an associated sub-basin. The stream network mainly contains stream reach and sub-basin characteristics such as stream length, direction of water flow, reservoir characteristics like surface area, and local and total drainage areas. For example, the areas of the sub-basin range from 0.009 to $117 \mathrm{~km}^{2}$, with a median of $15.9 \mathrm{~km}^{2}$. However, mean water flow is not reported for each stream reach, suggesting that we cannot calculate the SS concentration at the stream reach scale, but can calculate the total yield SS for each associated sub-basin.

\subsubsection{Stream load data}

Suspended sediment concentration and daily flow data are collected to calculate the long-term (from 1985 to 2010) 


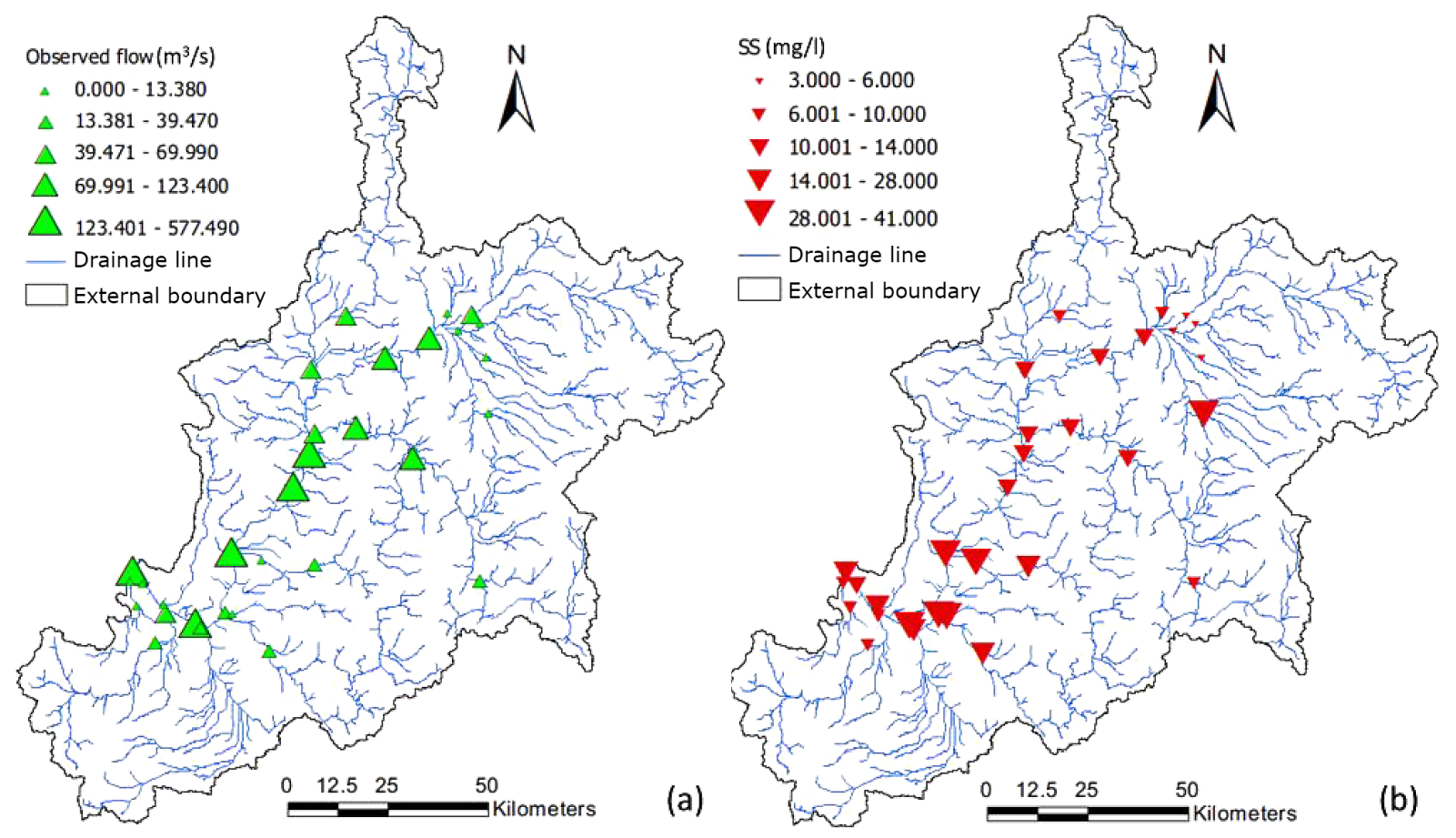

Figure 3. Schematic showing (a) the observed water flows $\left(\mathrm{m}^{3} \mathrm{~s}^{-1}\right)$ and (b) the observed SS concentration $\left(\mathrm{mg} \mathrm{L}^{-1}\right)$ at 31 monitoring stations.

mean SS flux at every monitoring station. Thirty-one monitoring stations were chosen for model calibration in this study (Fig. 1). SS concentration and daily flow data were collected at each site for the period from 1985 to 2010 by the National Land with Water Information (http://www1.river. go.jp/) monitoring network (Fig. 3). However, some streamflow gaging stations have short periods of record or missing flow values, but do not over $10 \%$ of the time periods. A streamflow record extension method called the Maintenance of Variance-Extension type 3 (MOVE.3) (Vogel and Stedinger, 1985) is employed to estimate missing flow values or to extend the record at a short-record station on the basis of daily streamflow values recorded at nearby, hydrologically similar index stations. On this basis, the FORTRAN Load Estimator (LOADEST), which uses time-series streamflow data and constituent concentrations to calibrate a regression model that describes constituent loads in terms of various functions of streamflow and time, is applied to estimate SS loads. The output regression model equations take the following general form (Runkel et al., 2004):

$$
\begin{aligned}
\ln \left(L_{i}\right) & =\alpha+b \ln Q+c \ln Q^{2}=\mathrm{d} \sin (2 \pi \cdot \mathrm{dtime}) \\
& +e \cos (2 \pi \cdot \mathrm{dtime})+f \cdot \mathrm{dtime}+g \cdot \mathrm{dtime}^{2}+\varepsilon,
\end{aligned}
$$

where $L_{i}$ is the calculated load for sample $i$; $Q$ is stream discharge; dtime is time in decimal years from the beginning of the calibration period; $\varepsilon$ is error; and $a, b, c d, e, f$, and $g$ are the fitted parameters in the multiple regression model. The number of parameters may be different at different stations, depending on the lowest Akaike information criterion (AIC) values (for details, please see Duan et al., 2013a, b).

$\mathrm{AIC}=2 k-2 \ln (L)$

where $k$ is the number of parameters in the statistical model, and $L$ is the maximized value of the likelihood function for the estimated model.

The mean annual load is normalized to the 2006 base year at the 31 monitoring stations to address the problem of incompatibility in periods of record by using normalizing or detrending methods (for the detailed process, please see Schwarz et al., 2006).

\subsubsection{Sediment source data}

SS source variables tested in the Ishikari SPARROW model include estimates of developing lands, forest lands, agricultural lands, and stream channels. Estimates of land use were developed using data derived from the Policy Bureau of the Ministry of Land, Infrastructure, Transport and Tourism, Japan, 2006, which mainly contains 11 types of land use (see Fig. 4). It was then merged into four types: developing land, forest land, agricultural land, and water land. Finally, different lands are allocated to individual sub-basins using GIS zonal processes. Arc Hydro Tools is employed to get the reach length, which denotes the streambed source. 


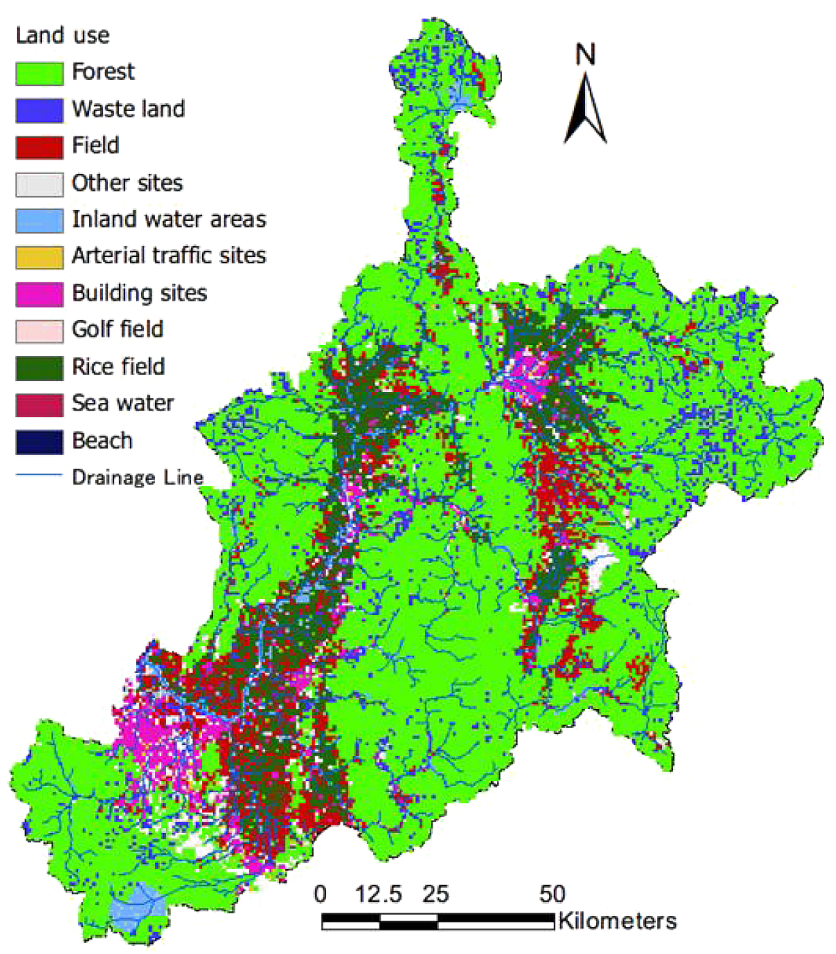

Figure 4. Land use of the Ishikari River basin, 2006.

\subsubsection{Environmental setting data}

Climatic and landscape characteristics considered candidates for SS transport predictors include climate, topography and soil (Duan et al., 2012; Asselman et al., 2003; Dedkov and Mozzherin, 1992). Here, slope, soil permeability, and precipitation are used to evaluate the influences of "land-towater" delivery terms. Basin slope is obtained using the GIS surface tool (see Fig. 5a). Soil permeability and clay content (see Fig. 5b) are estimated using data derived from the 1:5000000-scale FAO/UNESCO Soil Map of the World (FAO-UNESCO-ISRIC, 1988) and the National and Regional Planning Bureau, Japan. Mean annual precipitation data, representing the 20-year (1990-2010) average, were obtained from daily precipitation data at 161 weather stations (see Fig. S1 in the Supplement) in Hokkaido from 1990 to 2010; that is, we first interpolated the mean annual precipitation over Hokkaido using a conventional Kriging technique on the basis of 161 stations, and then clipped the mean annual precipitation distribution for the Ishikari River basin. Finally, all these watershed average values were used to calculate estimates for each sub-basin in the Ishikari model area using the ZONALMEAN and ZONALSTATISTICAL functions (zonal spatial analyst methods) of ArcGIS 10.

\subsection{Model calibration and application}

Considering that the calibration of the SPARROW model requires long-term averaging and load adjustments for changes in flow and sources, the final SPARROW model was statistically calibrated using estimates of mean annual SS fluxes at 31 monitoring stations (see input data). The explanatory variables represented statistically significant or otherwise important geospatial variables, and the measures of statistically significance are based on statistical evaluations of the $t$ statistics (ratio of the coefficient value to its standard error). The $t$ statistics are asymptotically distributed as a standard normal. The statistical significance $(\alpha=0.05)$ of the coefficients for each of the SS source terms (which were constrained to be positive) were determined by using a one-sided $t$ test, and the significance of the coefficients for each of the land-to-water delivery terms (which were allowed to be positive or negative, reflecting either enhanced or attenuated delivery, respectively) and the variables representing SS loss in free-flowing streams and impoundments were determined by using a twosided $t$ test (Schwarz et al., 2006). The yield R-squared $\left(R^{2}\right)$, the root mean squared error (RMSE), and the residuals for spatial patterns were the conventional statistical diagnostics used to assess the overall SPARROW model accuracy and performance.

According to the equations of SPARROW, the calibrated model can be used to identify the largest local SS sources; that is, the sediment source contributing the most to the incremental SS yield for each catchment in the Ishikari River basin can be calculated. In addition, the models can be used to estimate the contribution from each sediment source to the total SS loads predicted for each reach. Total loads were the predicted load contributed from all upstream landscape sediment sources. Finally, the factors that affect mean annual transport in the Ishikari River basin can be identified.

\section{Results and discussion}

\subsection{Model calibration}

Model calibration results for the log transforms of the summed quantities in Eq. (1) and nonlinear least-squares estimates are presented in Table 2, which explains approximately $96 \%\left(R^{2}\right)$ of the spatial variation in the natural logarithm of mean annual SS flux $\left(\mathrm{kg} \mathrm{yr}^{-1}\right)$, with a mean square error (MSE) of $0.323 \mathrm{~kg} \mathrm{yr}^{-1}$, suggesting that the SS predicted by the model has litter error compared with the observation load.

The plot of predicted and observed SS flux is shown in Fig. 6, demonstrating model accuracy over a wide range of predicted flux and stream sizes. Generally, for a good SPARROW model, the graphed points should exhibit an even spread about the one-to-one line (the straight line in Fig. 6) with no outliers. However, a common pattern expressed in Fig. 6 for the final SPARROW SS model is the tendency for larger scatter among observations with smaller predicted fluxes - a pattern of heteroscedasticity. One likely cause of this pattern is greater error in the measurement of flux 
Table 2. SPARROW estimates of model statistics for Ishikari River basin SS.

\begin{tabular}{|c|c|c|c|c|}
\hline Model parameters & $\begin{array}{l}\text { Coefficient } \\
\text { units }\end{array}$ & $\begin{array}{l}\text { Estimated } \\
\text { coefficient }\end{array}$ & $\begin{array}{l}\text { Standard } \\
\text { error }\end{array}$ & $p$ value \\
\hline \multicolumn{5}{|c|}{ SS sources } \\
\hline Developing land & $\mathrm{kg} \mathrm{km}^{-2} \mathrm{yr}^{-1}$ & 1006.267 & 508.503 & 0.028 \\
\hline Forest land & $\mathrm{kg} \mathrm{km}^{-2} \mathrm{yr}^{-1}$ & 75.554 & 31.058 & 0.011 \\
\hline Agricultural land & $\mathrm{kg} \mathrm{km}^{-2} \mathrm{yr}^{-1}$ & 234.211 & 121.751 & 0.036 \\
\hline Stream bed (stream channels) & $\mathrm{kg} \mathrm{km}^{-2} \mathrm{yr}^{-1}$ & 123.327 & 99.567 & 0.113 \\
\hline \multicolumn{5}{|c|}{ Land-to-water loss coefficient } \\
\hline Slope & - & 0.349 & 0.094 & $<0.001$ \\
\hline Soil permeability & $\mathrm{hcm}^{-1}$ & -9.195 & 2.431 & $<0.001$ \\
\hline Precipitation & $\mathrm{mm}$ & 0.007 & 0.002 & $<0.002$ \\
\hline \multicolumn{5}{|c|}{ In-stream loss rate } \\
\hline Small stream (drainage area $\leq 200 \mathrm{~km}^{2}$ ) & day $^{-1}$ & -0.044 & 0.011 & $<0.001$ \\
\hline Big stream (drainage area $>200 \mathrm{~km}^{2}$ ) & day $^{-1}$ & 0.000012 & 0.0068 & $>0.050$ \\
\hline Reservoir loss & $\mathrm{m} \mathrm{yr}^{-1}$ & 26.283 & 4.364 & $<0.001$ \\
\hline \multicolumn{5}{|c|}{ Model diagnostics } \\
\hline Mean square error & 0.32 & & & \\
\hline Number of observations & 31 & & & \\
\hline R-squared & 0.96 & & & \\
\hline
\end{tabular}

Notes: SPARROW, SPAtially Referenced Regression on Watershed; kg, kilograms; km, kilometers; yr, year; >, more than; <, less than. This table shows overall model calibration results, statistical parameter estimates, standard errors, and probability levels for modeled explanatory variables representing sediment sources, landscape factors affecting the delivery of sediment from uplands to streams (land-to-water), and in-stream and reservoir storage. All sources and storage terms are constrained to non-negative estimates for more physically realistic simulations of sediment transport. Because of this specification, the statistical significance for source and aquatic storage coefficient estimates are reported as a one-sided $p$ statistic. Probability levels for land-to-water parameters are two-sided values (Schwarz et al., 2006).

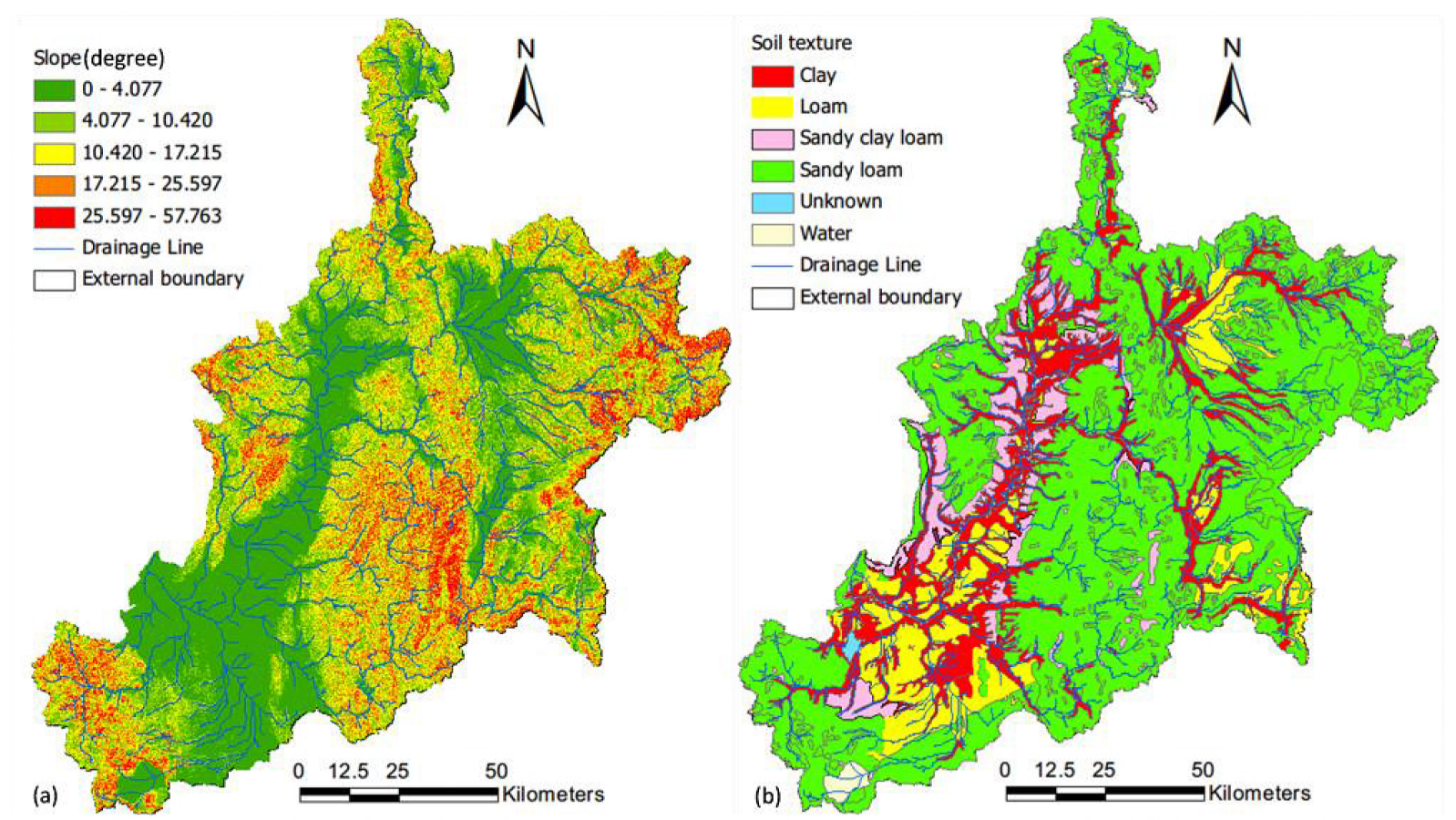

Figure 5. Schematic showing the slope (a) and soil texture (b) in the Ishikari River basin. 


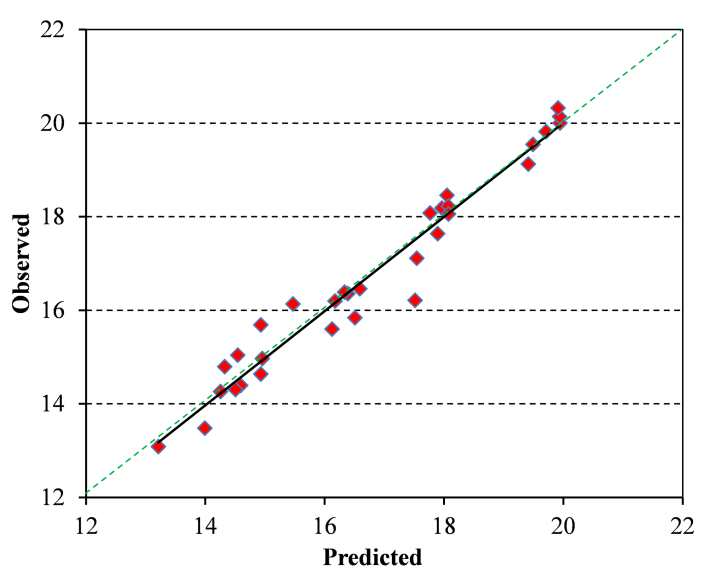

Figure 6. Observed and predicted SS flux $\left(\mathrm{kg} \mathrm{yr}^{-1}\right)$ at 31 monitoring sites included in the Ishikari SPARROW model (Natural logarithm transformation applied to observed and predicted values; the black line is the trend line, the green dashed line is a $1: 1$ line).

in small sub-basins due to greater variability in flow or to greater relative inhomogeneity of sediment sources within small sub-basins (Schwarz et al., 2006). Appropriate assignment of weights reflecting the relative measurement error in each observation (plus an additional common model error) can improve the coefficient estimates and correct the inference of coefficient error if the heteroscedasticity is caused by measurement error. On the other hand, the observations can be weighted to improve the coefficient estimates and correct their estimates of error if the heteroscedasticity is due to structural features of the SPARROW model. Figure 7 shows the standardized residuals at the 31 monitoring sites. Monitoring sites with overpredictions $(<0)$ mainly exist in the middle area of the Ishikari River basin, and underpredictions $(>0)$ exist in the upper and lower areas. The Studentized residual is useful for identifying outliers and, if greater than 3.6, is generally considered an outlier warranting further investigation (Schwarz et al., 2006). Overall, the final model does not show evidence of large prediction biases over the monitoring sites.

With the exception of stream channels, all of the source variables modeled are statistically significant ( $p$ value $<0.05$ ), with the estimated coefficient representing an approximate estimate of mean sediment yield for the associated land use (Table 2). The largest intrinsic sediment yield is associated with developing land, the estimated value of which is around $1006 \mathrm{~kg} \mathrm{~km}^{-2} \mathrm{yr}^{-1}$. Land development, including removing cover and developing cuts and fills, can increase potential erosion and sediment hazards on-site by changing water conveyance routes, soil compaction (both planned and unplanned), longer slopes and more and faster stormwater runoff. With the analysis of factors affecting sediment transport from uplands to streams (mean basin slope, reservoirs, physiography, and soil permeability), developing land was also the largest sediment source

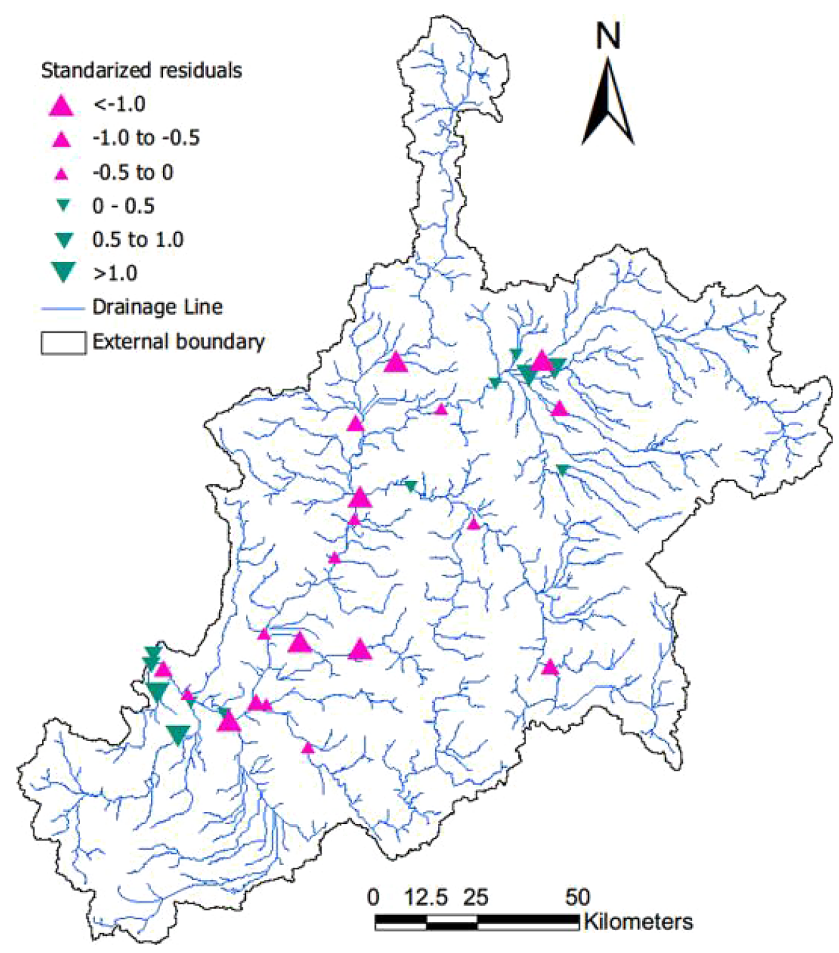

Figure 7. Model residuals for 31 monitoring stations used to calibrate the final Ishikari SPARROW model.

reported in Brakebill et al. (2010) and Schwarz (2008). Agricultural land has the second highest sediment yield, with an estimated value of around $234 \mathrm{~kg} \mathrm{~km}^{-2} \mathrm{yr}^{-1}$, and forest land has the lowest sediment yield, with an estimated value of around $76 \mathrm{~kg} \mathrm{~km}^{-2} \mathrm{yr}^{-1}$.

Land-to-water delivery for sediment land sources is powerfully mediated by watershed slope, soil permeability, and rainfall, all of which are statistically significant (Table 2). As expected, Table 2 shows that sediment produced from land transport to rivers is most efficient in areas with greater basin slope, less permeable soils, and greater rainfall, which is consistent with the results calculated by Brakebill et al. (2010). The alteration of these factors can directly and indirectly cause changes in sediment degradation and deposition, and, finally, to the sediment yield (Luce and Black, 1999; Nelson and Booth, 2002). Increased rainfall amounts and intensities can directly increase surface runoff, leading to greater rates of soil erosion (Nearing et al., 2005; Ran et al., 2012) with consequences for productivity of farmland (Julien and Simons, 1985). Watershed slope and soil permeability have a powerful influence on potential surface runoff as they affect the magnitude and rate of eroded sediment that may be transported to streams (Brakebill et al., 2010).

The coefficient for in-stream loss indicates that sediment is removed from large streams (about $0.000012 \mathrm{day}^{-1}$ ) and accumulates in small streams (about $-0.044 \mathrm{day}^{-1}$ ). These 

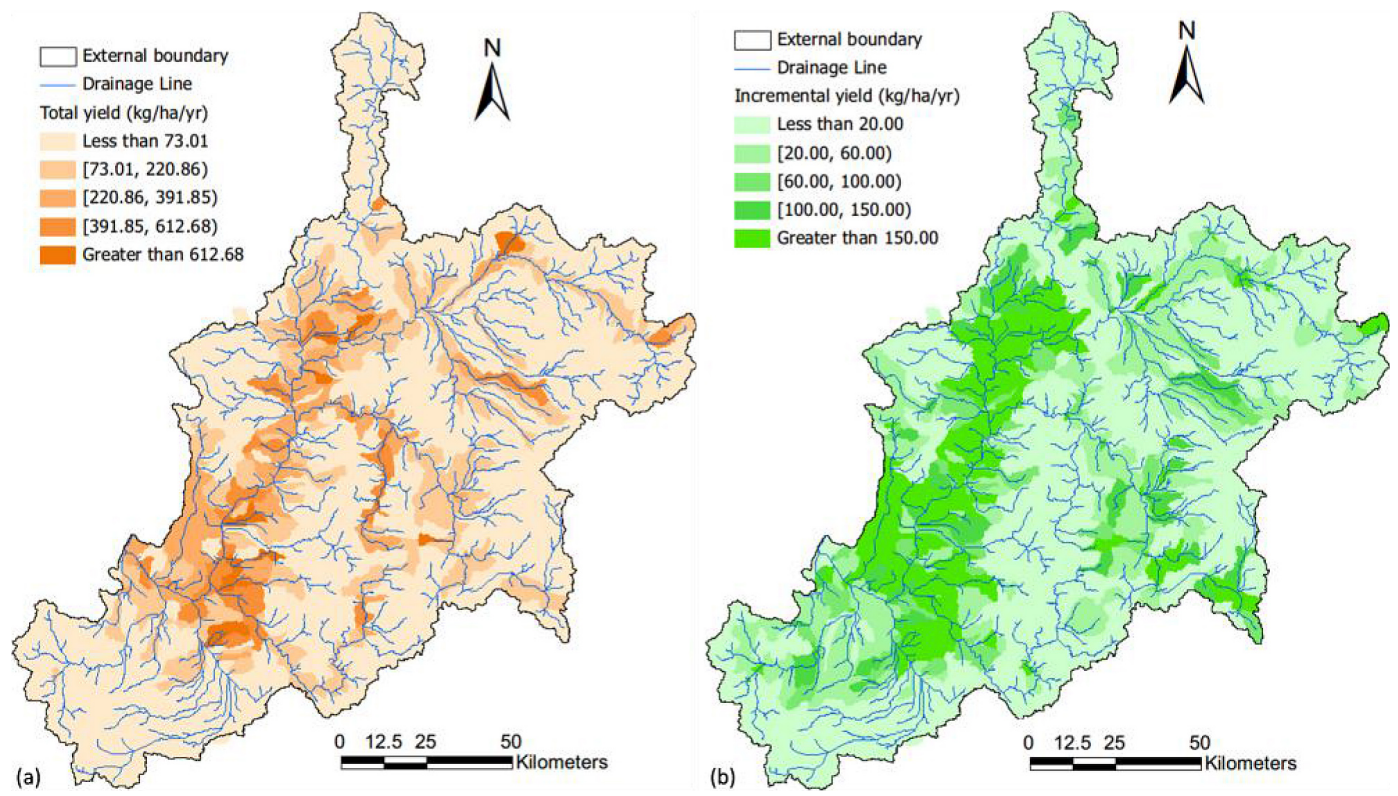

Figure 8. Map showing the spatial distribution of total suspended sediment yields (a) and incremental suspended sediment yields (b) estimated by SPARROW.

results run contrary to several published examples. For example, Schwarz (2008) argued that greater streamflow causes an increase in the amount of sediment generated from stream channels. The reasons for these results could be the criterion of the two kinds of streams. In this study, streams with drainage area $<200 \mathrm{~km}^{2}$ are shallow, small streams, which tend to attenuate the sediments; on the contrary, streams with drainage area $>200 \mathrm{~km}^{2}$ are big streams, which tend to create the sediments. Sediment storage is statistically significant in reservoirs (dams), the estimated value of which is around $26 \mathrm{~m} \mathrm{yr}^{-1}$. This value is much less than the coefficient of $235 \mathrm{~m} \mathrm{yr}^{-1}$ reported for the Chesapeake Bay watershed (SPARROW model; Brakebill et al., 2010), one possible reason for which maybe is that the reservoirs in the Ishikari River basin have less storage capacity compared with the reservoirs in Chesapeake Bay. However, the value is similar to the $36 \mathrm{~m} \mathrm{yr}^{-1}$ computed by the conterminous US SPARROW model (Schwarz, 2008).

\subsection{Model application}

Because data from sampling stream networks suffer from sparseness of monitoring stations, spatial bias and basin heterogeneity, describing regional distributions and exploring transport mechanism of sediment is one of the challenges of sediment assessment programs. Through the stream network, SPARROW can link in-stream water quality to spatially referenced information on contaminant sources and other watershed attributes relevant to contaminant transport (Smith et al., 1997). After calibration, the SPARROW model of total suspended sediment can be applied to evaluate the stream- corridor sediment supply, storage, and transport properties and processes in a regional context, which can inform a variety of decisions relevant to resource managers. Here, in order to further explore and manage sediment sources, we predict and analyze the spatial distribution of total sediment and incremental sediment yields, and estimate the amount of sediment generated by source described in each incremental basin.

The total yields (load per area) represent the amount of sediment including upstream load and local catchment load contributing to each stream reach, and the incremental yields represent the amount of sediment generated locally independent of upstream supply, and contributing to each stream reach, normalized by the local catchment area (see Fig. S2) (Ruddy et al., 2006). Figure 8a shows the spatial distribution of the total yields, describing the sediment mass entering streams per unit area of the incremental drainages of the Ishikari River basin associated with the stream network (Fig. 1). It is mediated by climatic and landscape characteristics and delivered to the Ishikari Gulf of the Sea of Japan after accounting for the cumulative effect of aquatic removal processes. Figure 8a shows that total yields, ranging from 0.03 to $1190 \mathrm{~kg} \mathrm{ha}^{-1} \mathrm{yr}^{-1}\left(\right.$ mean $\left.=101 \mathrm{~kg} \mathrm{ha}^{-1} \mathrm{yr}^{-1}\right)$, concentrate in the sub-basin along the middle and lower reaches of the Ishikari River. Like total yields, much of the incremental sediment yields are distributed in similar areas (see Fig. 8b), the largest of which is greater than $150 \mathrm{~kg} \mathrm{ha}^{-1} \mathrm{yr}^{-1}$. These two kinds of predictions provide localized estimates of sediment that are useful in evaluating local contributions of sediment in addition to identifying ge- 


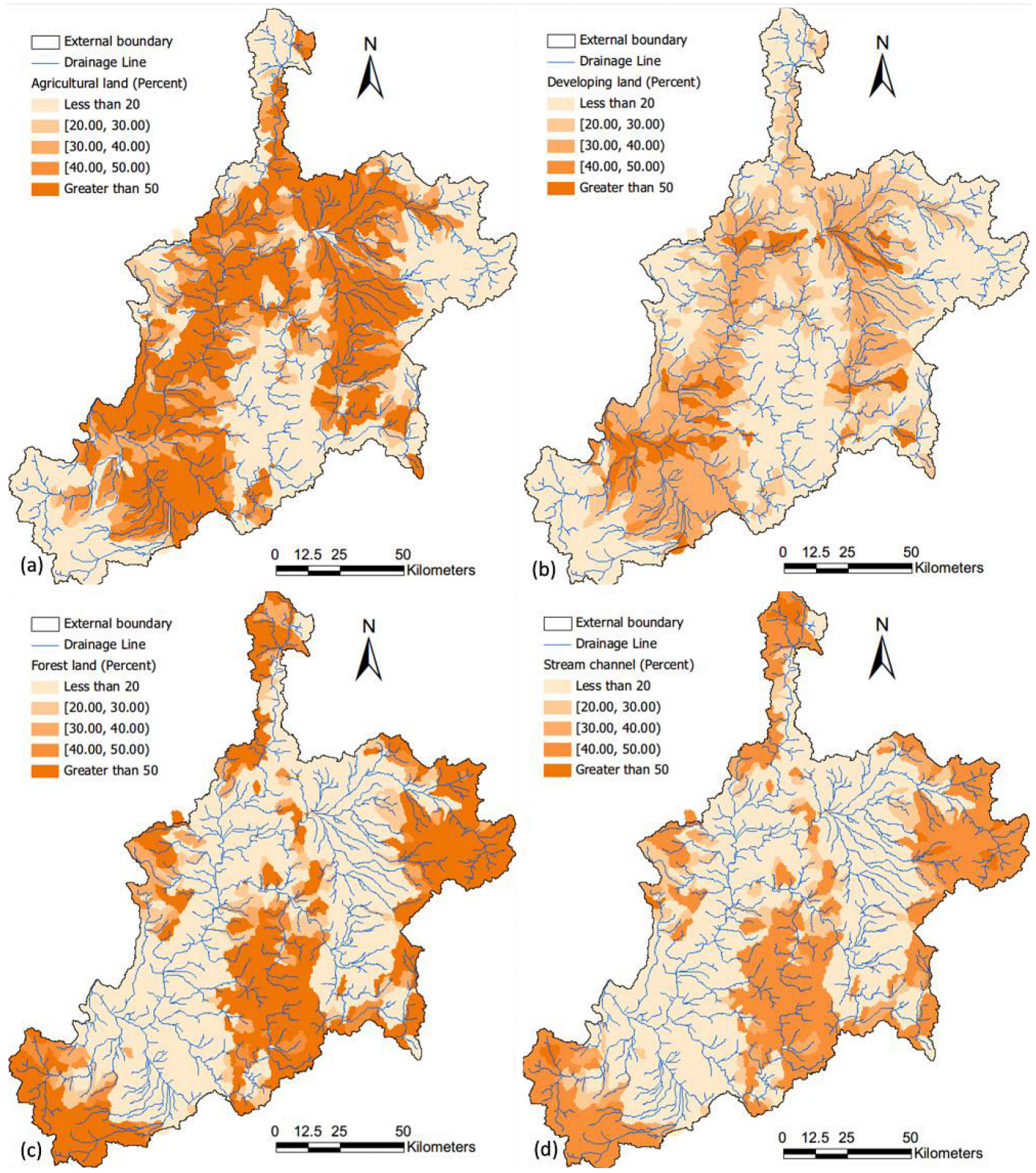

Figure 9. Maps showing the spatial distributions of independent sediment sources generated in each incremental catchment for (a) agricultural land, (b) developing land, (c) forested land, and (d) stream channels.

ographic areas of potential water quality degradation due to excessive sedimentation.

Figure 9 shows the percent of total incremental flux generated for (a) agricultural lands, (b) developing lands, (c) forested lands, and (d) stream channels, suggesting the relative contributions from the various sources at each subbasin. The contributions from these sources that go into the sub-basin yield (Fig. 8) are assessed by comparing predicted sub-basin yield with predicted yield from agricultural-land sediment yield (Fig. 9a); predicted developing-land sediment yield (Fig. 9b); predicted forest-land sediment yield (Fig. 9c); and predicted steam channel yield (Fig. 9d). Gen- erally, the spatial distribution of these contributions from different sources is in accordance with land use (Fig. 4). On average, we can see that $35 \%$ of the incremental flux is from agricultural lands, which is the largest of all sources; the second largest is from forested lands, the value of which is around $23 \%$, followed by developing lands $(23 \%)$; the least is from stream channels, with a value of $19 \%$.

\subsection{Uncertainty analysis}

Uncertainty always exists in hydrological models such as SPARROW and therefore cannot but imperfectly reflect real- 
ity. The sources of uncertainty in this study include (1) resolution of the geospatial data, (2) quality of the sediment loads used to calibrate the model, and (3) limitations of the modeling approach in representing the environmental processes accurately (Alexander et al., 2007). First, the hydrologic network was derived from a $50 \mathrm{~m}$ digital elevation model (DEM), which potentially deviates from the actual stream network, causing the discrepancy of stream reach and subbasin characteristics such as stream length and local and total drainage area. This will lead to spatial uncertainty, although that uncertainty is generally reflected in the SPARROW model errors after the calibration process (Alexander et al., 2007). Another cause of uncertainty is the suitability of using SS grab samples at the 31 monitoring sites for model calibration to reflect the normal conditions in-stream. Also, the SS loads at some monitoring stations were estimated using the MOVE. 3 and LOADEST techniques (Runkel et al., 2004; Duan et al., 2013a, b), which also have some uncertainties.

\section{Conclusions}

In this study, we developed a SPARROW-based sediment model for surface waters in the Ishikari River basin, the largest watershed in Hokkaido, Japan. This model is based on stream water quality monitoring records collected at 31 stations for the period 1985 to 2010 and uses four source variables including developing lands, forest lands, agricultural lands, and steam channels, three landscape delivery variables including slope, soil permeability, and precipitation, two instream loss coefficients including small streams (drainage area $\leq 200 \mathrm{~km}^{2}$ ) and big streams (drainage area $>200 \mathrm{~km}^{2}$ ), and reservoir attenuation. Significant conclusions on the calibration procedure and model application are summarized below. Calibration results explain approximately $96 \%$ of the spatial variation in the natural logarithm of mean annual SS flux $\left(\mathrm{kg} \mathrm{km}^{-2} \mathrm{yr}^{-1}\right)$ and display relatively small prediction errors on the basis of 31 monitoring stations. Developing land is associated with the largest intrinsic sediment yield at around $1006 \mathrm{~kg} \mathrm{~km}^{-2} \mathrm{yr}^{-1}$, followed by agricultural land $\left(234 \mathrm{~kg} \mathrm{~km}^{-2} \mathrm{yr}^{-1}\right)$. Greater basin slope, less permeable soils, and greater rainfall can directly and indirectly enable sediment transport from land into streams. Reservoir attenuation $\left(26 \mathrm{~m} \mathrm{yr}^{-1}\right)$ is statistically significant, suggesting that reservoirs can play a dramatic role in sediment interception. The percent of total incremental flux generated for agricultural lands, developing lands, forested lands, and stream channels is 35, 23, 23 and $19 \%$, respectively. Sediment total yields and incremental yields concentrate in the sub-basin along the middle and lower reaches of the Ishikari River, showing which sub-basin is most susceptible to erosion. Combined with land use, management actions should be designed to reduce sedimentation of agricultural lands and developing lands in the sub-basin along the middle and lower reaches of the Ishikari River. Our results suggest several areas for further research, including explicit representation of flow and sediment discharge from each stream and in total to the Sea of Japan, more accurate representation of spatial data in SPARROW, and the design of pollutant reduction strategies for local watersheds.

This study also has a number of shortcomings and suggests several areas for future work. Some important model parameters lack statistical significance, for example, statistically insignificant model components and inaccuracies associated with river systems, which contain a source variable (stream channels), and big streams with drainage area $>200 \mathrm{~km}^{2}$. These findings are contrary to the findings of other studies (Brakebill et al., 2010). In addition, the predictions of the model pertain to mean-annual conditions, not necessarily critical conditions such as low-flow conditions. The reason for these shortcomings derives from the following points: (1) the hydrologic network was derived from a $50 \mathrm{~m}$ digital elevation model (DEM), which potentially deviates from the actual stream network; (2) due to a lack of water discharge in all streams, stream velocity was replaced with the drainage area to classify fast and slow streams; and (3) the calibration data only incorporate monitored load data from a limited number of stations with long-term data.

Excessive sedimentation can have a variety of adverse effects on aquatic ecosystems and water resource infrastructure. Analysis of sediment production and transport mechanisms is therefore necessary to describe and evaluate a basin's water quality conditions in order to provide guidance for development of water quality indicators and pollution prevention measures (Buggy and Tobin, 2008; Meals et al., 2010). As illustrated here, the SPARROW model is a valuable tool that can be used by water resource managers in water quality assessment and management activities to support regional management of sediment in large rivers and estuaries.

\section{The Supplement related to this article is available online at doi:10.5194/hess-19-1293-2015-supplement.}

Acknowledgements. This study is sponsored by National Natural Science Foundation of China (No. 41471460) and "One Hundred Talents Program" of Chinese Academy of Sciences, the Kyoto University Sustainability/Survivability Science for a Resilient Society Adaptable to Extreme Weather Conditions Global COE program and the Global Center for Education and Research on Human Security Engineering for Asian Megacities, the Postdoctoral fellowship of Japan Society for the Promotion of Science (P12055), JSPS KAKENHI grant number 24.02055 and the JSPS Grant-in-Aid for Young Scientists (B) (KAKENHI Wakate B, 90569724). We also wish to acknowledge Anne B. Hoos and John W. Brakebill of the US Geological Survey for their help with the use of the SPARROW model. The first author would like to thank the China Scholarship Council (CSC) for his PhD scholarships. 
Edited by: M. Mikos

\section{References}

Ahn, Y. S., Nakamura, F., Kizuka, T., and Nakamura, Y.: Elevated sedimentation in lake records linked to agricultural activities in the Ishikari River floodplain, northern Japan, Earth Surf. Proc. Land, 34, 1650-1660, doi:10.1002/esp.1854, 2009.

Alexander, R. B., Smith, R. A., and Schwarz, G. E.: Effect of stream channel size on the delivery of nitrogen to the Gulf of Mexico, Nature, 403, 758-761, doi:10.1038/35001562, 2000.

Alexander, R. B., Smith, R. A., Schwarz, G. E., Boyer, E. W., Nolan, J. V., and Brakebill, J. W.: Differences in phosphorus and nitrogen delivery to the Gulf of Mexico from the Mississippi River Basin, Environ. Sci. Technol., 42, 822-830, doi:10.1021/es0716103, 2007.

Asahi, K., Kato, K., and Shimizu, Y.: Estimation of Sediment Discharge Taking into Account Tributaries to the Ishikari River, J. Nat. Disast. Sci., 25, 17-22, 2003.

Asselman, N. E. M., Middelkoop, H., and Van Dijk, P. M.: The impact of changes in climate and land use on soil erosion, transport and deposition of suspended sediment in the River Rhine, Hydrol. Process., 17, 3225-3244, doi:10.1002/hyp.1384, 2003.

Bilotta, G. S. and Brazier, R. E.: Understanding the influence of suspended solids on water quality and aquatic biota, Water Res., 42, 2849-2861, doi:10.1016/j.watres.2008.03.018, 2008.

Brakebill, J. W., Ator, S. W., and Schwarz, G. E.: Sources of Suspended Sediment Flux in Streams of the Chesapeake Bay Watershed: A Regional Application of the SPARROW Modell, J. Am. Water Resour. Assoc., 46, 757-776, doi:10.1111/j.17521688.2010.00450.x, 2010.

Buggy, C. J. and Tobin, J. M.: Seasonal and spatial distribution of metals in surface sediment of an urban estuary, Environ. Pollut., 155, 308-319, doi:10.1016/j.envpol.2007.11.032, 2008.

Chapra, S. C.: Surface Water-Quality Modelling, McGraw-Hill, New York, 1997.

Conley, D. J., Paerl, H. W., Howarth, R. W., Boesch, D. F., Seitzinger, S. P., Havens, K. E., Lancelot, C., and Likens, G. E.: Controlling eutrophication: nitrogen and phosphorus, Science, 323, 1014-1015, doi:10.1126/science.1167755, 2009.

Dedkov, A. P. and Mozzherin, V. I.:. Erosion and sediment yield in mountain regions of the world. Erosion, debris flows and environment in mountain regions, Proceedings of the International Symposium, 5-9 July 1992, Chengdu, China, IAHS Publ., 209, 29-36, 1992.

Drewry, J. J., Newham, L., and Croke, B.: Suspended sediment, nitrogen and phosphorus concentrations and exports during stormevents to the Tuross estuary, Australia, J. Environ. Manage., 90, 879-887, doi:10.1016/j.jenvman.2008.02.004, 2009.

Duan, W., He, B., Takara, K., Luo, P., and Yamashiki, Y.: Estimating the Sources and Transport of Nitrogen Pollution in the Ishikari River Basin, Japan, Adv. Mater. Res., 518, 3007-3010, doi:10.4028/www.scientific.net/AMR.518-523.3007, 2012.

Duan, W., Takara, K., He, B., Luo, P., Nover, D., and Yamashiki, Y.: Nutrients and Suspended Sediment Load Estimates for the Ishikari River Basin, Japan, Over a Decade, Kyoto University, Disast. Prevent. Res. Inst. Annu., 56, 59-64, 2013 a.
Duan, W., Takara, K., He, B., Luo, P., Nover, D., and Yamashiki, Y.: Spatial and temporal trends in estimates of nutrient and suspended sediment loads in the Ishikari River, Japan, 1985 to 2010, Sci. Total Environ., 461, 499-508, doi:10.1016/j.scitotenv.2013.05.022, 2013b.

Fang, N. F., Shi, Z. H., Li, L., and Jiang, C.: Rainfall, runoff, and suspended sediment delivery relationships in a small agricultural watershed of the Three Gorges area, China, Geomorphology, 135, 158-166, doi:10.1016/j.geomorph.2011.08.013, 2011.

FAO-UNESCO-ISRIC: FAO-UNESCO soil map of the world: revised legend, FAO, Rome, Italy, 1988.

Hoos, A. B. and McMahon, G.: Spatial analysis of instream nitrogen loads and factors controlling nitrogen delivery to streams in the southeastern United States using spatially referenced regression on watershed attributes (SPARROW) and regional classification frameworks, Hydrol. Process., 23, 2275-2294, doi:10.1002/hyp.7323, 2009.

Hunter, H. M. and Walton, R. S.: Land-use effects on fluxes of suspended sediment, nitrogen and phosphorus from a river catchment of the Great Barrier Reef, Australia, J. Hydrol., 356, 131146, doi:10.1016/j.jhydrol.2008.04.003, 2008.

Ishida, T., Nakayama, K., Okada, T., Maruya, Y., Onishi, K., and Omori, M.: Suspended sediment transport in a river basin estimated by chemical composition analysis, Hydrol. Res. Lett., 4, 55-59, doi:10.3178/hrl.4.55, 2010, 2010.

Julien, P. Y. and Simons, D. B.: Sediment transport capacity of overland flow, Trans. Am. Soc. Agric. Eng., 28, 755-762, 1985.

Lal, R.: Soil degradation by erosion, Land Degrad. Dev., 12, 519539, doi:10.1002/ldr.472, 2001.

Langland, M. J. and Cronin, T. M.: A summary report of sediment processes in Chesapeake Bay and watershed, Water-Resources Investigations Report 03-4123, US Geological Survey, 109 pp., 2003.

Le, C., Zha, Y., Li, Y., Sun, D., Lu, H., and Yin, B.: Eutrophication of lake waters in China: cost, causes, and control, Environ Manage., 45, 662-668, doi:10.1007/s00267-010-9440-3, 2010.

Luce, C. H. and Black, T. A.: Sediment production from forest roads in western Oregon, Water Resour. Res., 35, 2561-2570, doi:10.1029/1999WR900135, 1999.

McMahon, G., Alexander, R. B., and Qian, S.: Support of total maximum daily load programs using spatially referenced regression models, J. Water Resour. Pl. Manage., 129, 315-329, doi:10.1061/(ASCE)0733-9496(2003)129:4(315), 2003.

Meade, R. H., Dunne, T., Richey, J. E., De M Santos, U., and Salati, E.: Storage and remobilization of suspended sediment in the lower Amazon River of Brazil, Science, 228, 488-490, doi:10.1126/science.228.4698.488, 1985.

Meals, D. W., Dressing, S. A., and Davenport, T. E.: Lag time in water quality response to best management practices: A review, J. Environ. Qual., 39, 85-96, doi:10.2134/jeq2009.0108, 2010.

Mizugaki, S., Onda, Y., Fukuyama, T., Koga, S., Asai, H., and Hiramatsu, S.: Estimation of suspended sediment sources using $137 \mathrm{Cs}$ and $210 \mathrm{Pbex}$ in unmanaged Japanese cypress plantation watersheds in southern Japan, Hydrol. Process., 22, 4519-4531, doi:10.1002/hyp.7053, 2008.

Nearing, M. A., Jetten, V., Baffaut, C., Cerdan, O., Couturier, A., Hernandez, M., Le Bissonnais, Y., Nichols, M. H., Nunes, J. P., and Renschler, C. S.: Modeling response of soil erosion and 
runoff to changes in precipitation and cover, Catena, 61, 131154, doi:10.1016/j.catena.2005.03.007, 2005.

Nelson, E. J. and Booth, D. B.: Sediment sources in an urbanizing, mixed land-use watershed, J. Hydrol., 264, 51-68, doi:10.1016/S0022-1694(02)00059-8, 2002.

Preston, S. D., Alexander, R. B., Woodside, M. D., and Hamilton, P. A.: SPARROW modeling: Enhancing understanding of the nation's water quality, US Geological Survey Fact Sheet 20093019, US Geological Survey, Reston, VA, 2009.

Ran, Q., Su, D., Li, P., and He, Z.: Experimental study of the impact of rainfall characteristics on runoff generation and soil erosion, J. Hydrol., 424, 99-111, doi:10.1016/j.jhydrol.2011.12.035, 2012.

Ruddy, B. C., Lorenz, D. L., and Mueller, D. K.: County-level estimates of nutrient inputs to the land surface of the conterminous United States, 1982-2001, US Geol. Surv. Sci. Invest. Rep. 2006-5012, 17 pp., http://pubs.usgs.gov/sir/2006/5012/pdf/ sir2006_5012.pdf (last access: 9 April 2013), 2006.

Runkel, R. L., Crawford, C. G., and Cohn, T. A.: Load Estimator (LOADEST): A FORTRAN Program for Estimating Constituent Loads in Streams and Rivers, US Geological Survey, Reston, Virginia, 69 pp., 2004.

Schwarz, G. E.: A Preliminary SPARROW Model of Suspended Sediment for the Conterminous United States, US Geological Survey Open-File Report 2008-1205, US Geological Survey, Reston, VA, http://pubs.usgs.gov/of/2008/1205 (last access: 4 September 2013), 2008.

Schwartz, G. E., Hoos, A. B., Alexander, R. B., and Smith, R. A.: The SPARROW surface water-quality model: Theory, application, and user documentation, US Geological Survey Techniques and Methods Report 6-B3, 248 pp., http://pubs.usgs.gov/ tm/2006/tm6b3/PDF.htm (last access: 9 April 2013), 2006.
Smith, R. A., Schwarz, G. E., and Alexander, R. B.: Regional interpretation of water-quality monitoring data, Water Resour. Res., 33, 2781-2798, doi:10.1029/97WR02171, 1997.

Somura, H., Takeda, I., Arnold, J. G., Mori, Y., Jeong, J., Kannan, N., and Hoffman, D.: Impact of suspended sediment and nutrient loading from land uses against water quality in the Hii River basin, Japan, J. Hydrol., 450, 25-35, doi:10.1016/j.jhydrol.2012.05.032, 2012.

Srinivasa, G. S., Ramakrishna, R. M., and Govil, P. K.: Assessment of heavy metal contamination in soils at Jajmau (Kanpur) and Unnao industrial areas of the Ganga Plain, Uttar Pradesh, India, J. Hazard. Mater., 174, 113-121, doi:10.1016/j.jhazmat.2009.09.024, 2010.

Trimble, S. W.: Contribution of stream channel erosion to sediment yield from an urbanizing watershed, Science, 278, 1442-1444, doi:10.1126/science.278.5342.1442, 1997.

USEPA - US Environmental Protection Agency: Wadeable streams assessment: a collaborative survey of the nation's streams, Washington, D.C., 98 pp., 2006.

Vogel, R. M. and Stedinger, J. R.: Minimum variance streamflow record augmentation procedures, Water Resour. Res., 21, 715723, doi:10.1029/WR021i005p00715, 1985.

Wolman, M. G.: A cycle of sedimentation and erosion in urban river channels, Geograf. Ann. A, 385-395, doi:10.1177/0309133311414527, 1967.

Wongsa, S. and Shimizu, Y.: Modelling artificial channel and land-use changes and their impact on floods and sediment yield to the Ishikari basin, Hydrol. Process., 18, 1837-1852, doi:10.1002/hyp.1450, 2004. 